\title{
Effects of secondary metabolites produced by different cyanobacterial populations on the freshwater zooplankters Brachionus calyciflorus and Daphnia pulex
}

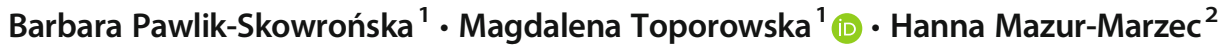

Received: 26 July 2018 / Accepted: 13 February 2019 / Published online: 27 February 2019

(C) The Author(s) 2019

\begin{abstract}
Cyanobacterial blooms in eutrophic water bodies are a worldwide problem. Combined effects of mixtures of secondary metabolites produced by different cyanobacterial species on aquatic fauna are still not well recognised. We compared the survivorship of Brachionus calyciflorus Pallas (Rotifera) and Daphnia pulex Leyding (Cladocera) exposed to pure microcystin LR (MC-LR), anatoxin-a (ANTX) and to five extracts obtained from bloom-forming cyanobacteria Microcystis, Planktothrix and Dolichospermum. The obtained results revealed different response of the organisms to high concentrations of pure MC-LR, ANTX and complex cyanobacterial extracts. The extracts' toxicity to invertebrates was higher than that exerted by pure cyanotoxins and was dependent on the composition of cyanobacterial metabolites: Microcystis spp. extract containing anabaenopeptins A and B, aeruginosamide, four variants of cyanopeptolins and five MCs was not toxic to either of the organisms, whereas Planktothrix agardhii extract (I), containing anabaenopeptins A, B, F, 915, oscillamide Y, five different aeruginosins and four variants of MC was more toxic to daphnids than to rotifers. The extracts of another $P$. agarhdii (II) biomass and two different biomass samples of Dolichospermum spp. also affected survivorship of the rotifer and cladoceran, however, to various extent. It strongly suggests that non-ribosomal oligopeptides, other than MCs, had essential contribution to the observed toxicity to invertebrates and their effects on particular species or populations can vary depending on the secondary metabolite profiles of cyanobacteria.
\end{abstract}

Keywords Microcystins $\cdot$ Anatoxin-a $\cdot$ Anabaenopeptins $\cdot$ Cyanopeptolins $\cdot$ Zooplankton

\section{Introduction}

Water blooms caused by cyanobacteria are an increasing global problem. Many of the bloom-forming species produce various toxins such as microcystins (MCs), anatoxin-a (ANTX),

Responsible editor: Vitor Manuel Oliveira Vasconcelos

Barbara Pawlik-Skowrońska

barbara.pawlik@up.lublin.pl

Magdalena Toporowska

magdalena.toporowska@up.lublin.pl

Hanna Mazur-Marzec

biohm@ug.edu.pl

1 Department of Hydrobiology and Protection of Ecosystems, University of Life Sciences in Lublin, Dobrzańskiego 37, 20-262 Lublin, Poland

2 Division of Marine Biotechnology, University of Gdańsk, al. Piłsudskiego 46, 81-378 Gdynia, Poland
anatoxin-a(S) (ANTX-S), saxitoxins (STX) and other metabolites harmful to aquatic organisms, including zooplankton species (Ferrão-Filho and Kozlowsky-Suzuki 2011; Metcalf and Codd 2012; Toporowska et al. 2014; Pearson et al. 2016; Bownik 2016; Osswald et al. 2007). In freshwaters affected by cyanobacterial blooms, replacement of larger planktonic invertebrates (e.g. Daphnia; Cladocera) by smaller cladocerans (e.g. Bosmina), rotifers and copepods has been reported (Leonard and Pearl 2005; Hansson et al. 2007). According to published reports, this phenomenon may be a consequence of (i) a reduction of the filtering efficiency of larger zooplankton species by filaments and colonies of cyanobacteria (DeMott et al. 2001); (ii) a deterioration of the quality of algal food (Tillmanns et al. 2008); and/ or (iii) harmful effects of cyanobacterial metabolites on different zooplankton genera and species (Hulot et al. 2012; Smutná et al. 2014). These effects, however, have been insufficiently recognised, yet.

Studies on cyanobacteria-zooplankton interactions have shown diverse and sometimes contradictory results (Tillmanns et al. 2008; Ger et al. 2014 and references therein). Most reports 
concern cell-bound (intracellular) compounds or effects of a single extracellular metabolite, especially MCs. For example, MC-producing Microcystis spp. as a diet inhibited growth rate, reproduction and lifespan of some Cladocera (Daphnia, Moina or Ceriodaphnia) and Rotifera (Lürling 2003; Geng and Xie 2008; Han et al. 2012). Zooplankton accumulates cyanotoxins by intestinal uptake and ingestion of cyanobacteria (Rohrlack et al. 2005), however, it can be also affected by toxins dissolved in water. Therefore, an increasing attention has been paid to the influence of the dissolved fraction of cyanobacterial metabolites on aquatic organisms, including zooplankton (Smutná et al. 2014; Ferrão-Filho et al. 2014; Barrios et al. 2015). During cyanobacterial mass development or cell lysis, especially during bloom collapse, a mixture of toxins and other cyanobacteria cell components occurs in water and can achieve high concentrations. For example, in a Polish lake with P. agardhii bloom $11 \mu \mathrm{g} / \mathrm{L}$ of dissolved MCs was found (Pawlik-Skowrońska et al. 2008), but much higher cyanotoxin concentrations (even up to $226.2 \mu \mathrm{g} \mathrm{MCs} / \mathrm{L}$ and up to $126 \mu \mathrm{g}$ cylindrospermopsin/L; Messineo et al. 2009) were determined in Italian freshwaters. During Microcystis bloom collapse, the concentrations of dissolved MCs reached up to $712 \mu \mathrm{g} / \mathrm{L}$ (Nasri et al. 2004) and even up to $1800 \mu \mathrm{g} / \mathrm{L}$ after treatment of bloom with an algicide (Jones and Orr 1994). The influence of cyanobacterial metabolites (other than known toxins) on zooplankton reaches an increasing interest (Blom et al. 2006; Czarnecki et al. 2006; Schwarzenberger et al. 2013a; Kohler et al. 2014) due to their inhibitory activity to some enzymes such as serine proteases, protein phosphatases, carboxypeptidases. Oligopeptides constitute a very large group of cyanobacterial products such as many variants of anabaenopeptins, aeruginosins and microginins (Lifshits and Carmeli 2012) commonly occurring in eutrophic water bodies at different concentrations. As reported by Schwarzenberger et al. (2013b), production of serine protease inhibitors such as micropeptins by $M$. aeruginosa was dependant on biogenic compounds ( $\mathrm{N}$ and $\mathrm{P}$ ) availability, which also increases cyanobacterial development in nutrientrich waters. Ecological and biological role of oligopeptides still remains unclear (Baumann and Jüttner 2008; Agha and Quesada 2014), albeit negative influence of some of them on aquatic organisms has been reported (Blom et al. 2006; Czarnecki et al. 2006; Kohler et al. 2014). We agree with the statement of Ger et al. (2014), that since cyanobacteria produce more than one bioactive metabolite, the unsystematic designation of toxicity based on a single well-identified compound is insufficient to assess the environmental impact of cyanobacterial bloom and should be revised. Therefore, the effects of complex mixtures of cyanobacterial secondary metabolites on zooplankton (and other aquatic organisms) should be thoroughly studied, what was recently strongly emphasised by Barrios et al. (2015).

The aim of this work was to compare the effect of pure cyanotoxins (MC-LR, ANTX) and complex mixtures of metabolites produced by different populations of bloom-forming cyanobacterial genera on the survivorship of two freshwater zooplankters of worldwide distribution. We also hypothesised that the non-ribosomal oligopeptides (other than MCs) produced by different cyanobacteria may essentially contribute to their toxicity to zooplankton.

\section{Materials and methods}

\section{Sampling and identification of cyanobacteria}

As indicated in Table 1, four samples of surface scum formed by the coccoid Microcystis spp. or Dolichospermum flosaquae (Brébisson ex Bornet \& Flahault) P. Wacklin, L. Hoffmann and J. Komárek or D. lemmermannii (Ricter) P. Wacklin, L. Hoffmann and J. Komárek, or Planktothrix

Table 1 Characteristics of the cyanobacterial biomasses sampled in the lakes and their crude extracts used in bioassays

\begin{tabular}{|c|c|c|c|c|c|c|}
\hline Lake & Species composition & Extract code & Chl-a (mg/L) & Total MCs (mg/L) & ANTX (mg/L) & $\begin{array}{l}\text { Toxins }(\mathrm{MCs}+\mathrm{ANTX}) \\
\text { to Chl-a ratio }\end{array}$ \\
\hline Wytyckie & $\begin{array}{l}\text { Microcystis aeruginosa }(90 \%) \\
\text { M. natans }(5 \%) \\
\text { M. wesenbergii }(5 \%)\end{array}$ & $\mathrm{A}$ & $7.90 \pm 0.24$ & $5.00 \pm 0.14$ & n.d. & 0.633 \\
\hline Syczyńskie & $\begin{array}{l}\text { Planktothrix agardhii I (97\%) } \\
\text { Aphanizomenon gracile }(2 \%) \text {, } \\
\text { Dolichospermum spp. }(1 \%)\end{array}$ & $\mathrm{B}$ & $29.66 \pm 0.07$ & $14.80 \pm 0.35$ & n.d. & 0.499 \\
\hline Syczyńskie & $\begin{array}{l}\text { P. agardhii } \mathrm{II}(99 \%) \\
\text { A. gracile }(1 \%)\end{array}$ & $\mathrm{C}$ & $115.51 \pm 13.65$ & $5.46 \pm 0.73$ & n.d. & 0.047 \\
\hline Syczyńskie & $\begin{array}{l}\text { Dolichospermum flos-aquae (98\%), } \\
\text { A. gracile }(2 \%)\end{array}$ & $\mathrm{D}$ & $10.88 \pm 2.99$ & $0.06 \pm 0.01$ & $0.31 \pm 0.01$ & 0.0345 \\
\hline Piaseczno & $\begin{array}{l}\text { Dolichospermum lemmermannii (99\%), } \\
\text { Dolichospermum spp. (1\%) }\end{array}$ & $\mathrm{E}$ & $70.48 \pm 3.99$ & $8.81 \pm 0.65$ & $2.05 \pm 0.15$ & 0.154 \\
\hline
\end{tabular}

n.d. not detected

Data are expressed as means $\pm \mathrm{SD}, n=3$ 
agardhii (Gomont) Anagnostidis and Komárek and one sample of $P$. agardhii bloom concentrated with a plankton net $(25$ $\mu \mathrm{m})$ were collected in the following spring-autumn seasons in three lakes-Piaseczno Lake (one sample), Wytyckie Lake (one sample) and Syczyńskie Lake (three samples) (E. Poland). The lakes differ in trophic status: from mesotrophic to hypertrophic, respectively. Taxonomic identification of cyanobacteria was carried out according to Komárek and Anagnostidis (1999, 2000, 2005) and Wacklin et al. (2009).

\section{Cyanobacterial biomass extraction}

A total of 15 to $20 \mathrm{~mL}$ of each mentioned above samples of cyanobacterial biomass were used to prepare aqueous extracts for bioassays and to determine the MCs and ANTX concentrations. Fresh biomass samples were sonicated for $5 \mathrm{~min}$. and after centrifugation $(14,000 \times \mathrm{g}$ for $10 \mathrm{~min}, 17$ $\left.{ }^{\circ} \mathrm{C}\right)$, supernatants were collected and frozen $\left(-20^{\circ} \mathrm{C}\right)$ until the day of cyanotoxin analysis and bioassays. Chlorophylla concentration (an indicator of the total cyanobacterial biomass) in the ethanol extracts was determined spectrophotometrically (at 665 and $750 \mathrm{~nm}$ ) according to the norm PN-ISO 10260 (2002).

A total of $10 \mathrm{~mL}$ of Microcystis spp. (A) and P. agardhiidominated (B) bloom samples were used to prepare extracts for LC-MS/MS analysis of cyanobacterial oligopeptides. Other cyanobacterial samples were not analysed for the detailed composition of oligopeptides other than MCs due to a lack of material. The samples were filtered onto $\mathrm{GF} / \mathrm{C}$ glassfibre filters (Whatman) and extracted with $5.0 \mathrm{~mL}$ of $5 \%$ acetic acid in MilliQ water by 1-min probe sonication with an ultrasonic disrupter followed by 15 -min bath sonication. After centrifugation $(10,000 \mathrm{~g}$ for $15 \mathrm{~min})$, supernatants were collected and subjected to LC-MS/MS analysis.

\section{HPLC-PDA analysis of microcystins}

A high-performance liquid chromatography-photodiode array detection system (Shimadzu) was used for microcystin (MC) detection in cyanobacterial extracts according to Lawton et al. (1994). Microcystins were separated using the following mobile phases: A, water acidified with $0.05 \%$ trifluoroacetic acid (TFA, Merck) and B, acetonitrile (Merck) acidified with $0.05 \%$ TFA (the gradient $30-100 \%$ ) at a flow rate of 0.7 $\mathrm{mL} / \mathrm{min}$ in a RP-18 Purosphere column $(125 \times 3 \mathrm{~mm}$, dp 5 $\mu \mathrm{m}$, Merck). The wavelength range for detection was 200 $300 \mathrm{~nm}$. For identification and quantitative analyses, MC-LR, MC-RR, MC-YR, MC-LA, MC-LY, MC-LF, MC-WR, MCHtyR (Alexis) were used as standards. Other MC variants were identified on the base of their specific absorption spectra, retention time and confirmed by LC-MS/MS analysis.

\section{HPLC-FLD analysis of anatoxin-a}

ANTX was determined using HPLC with fluorescence detection (FLD, Beckman). Ten microliters of each extract was reconstituted with $100 \mu \mathrm{l}$ of $0.1 \mathrm{M}$ sodium borate in a $2-\mathrm{mL}$ Eppendorf probe. Fifty microliters of $10 \%$ NBD-F (4-fluoro-7-nitrobenzofuran; Fluka) in acetonitrile was added and the mixture was allowed to stand $(10 \mathrm{~min})$ in the dark at room temperature. Fifty microliters of $1 \mathrm{M} \mathrm{HCl}$ was added to terminate the reaction and HPLC-FLD was performed using an RP-18 Purospher column $(125 \times 3 \mathrm{~mm}, 5 \mu \mathrm{m}$, Merck $)$ at 25 ${ }^{\circ} \mathrm{C}$. The mobile phases were A, water acidified with $0.05 \%$ trifluoroacetic acid (TFA, Merck) and B, acetonitrile (Merck) acidified with $0.05 \%$ TFA (45:55), at a flow rate of $0.6 \mathrm{~mL} / \mathrm{min}$. The detector parameters were as follows: excitation wavelength $470 \mathrm{~nm}$, emission wavelength $530 \mathrm{~nm}$. ANTX standard (Tocris, Bioscience) was used for identification and quantitative determinations of the toxin.

\section{LC-MS/MS analysis of oligopeptides}

Structural analyses of cyanobacterial peptides were performed using Agilent 1200 (Agilent Technologies, Waldboronn) coupled online to a hybrid triple quadrupole/linear ion trap mass spectrometer (QTRAP5500, Applied Biosystems, Sciex; Concorde, ON). As a mobile phase, a mixture of A ( $5 \%$ acetonitrile in MilliQ water plus $0.1 \%$ formic acid) and $\mathrm{B}(0.1 \%$ formic acid in acetonitrile) was used. Separation was performed on a Zorbax Eclipse XDB-C18 column $(4.6 \times 150$ $\mathrm{mm} ; 5 \mu \mathrm{m}$ ) (Agilent Technologies, Santa Clara, CA). Phase B was linearly increased from 15 to $75 \%$ in 5 min and then to $90 \%$ in the next $5 \mathrm{~min}$. This composition of the mobile phase was held for $5 \mathrm{~min}$ and brought back to $15 \%$ B in $1 \mathrm{~min}$. The column oven temperature was $35^{\circ} \mathrm{C}$, the flow rate was 0.6 $\mathrm{mL} / \mathrm{min}$ and the injection volume was $5 \mu \mathrm{L}$. The turbo ion spray $\left(550^{\circ} \mathrm{C}\right)$ voltage was $5.5 \mathrm{kV}$, with the nebuliser gas pressure and curtain gas pressures set at 60 p.s.i. and 20 p.s.i., respectively.

To characterise the structure of cyanobacterial peptides with the MS/MS system, the experiments were run using the information-dependent acquisition method (IDA) and in enhanced ion product mode (EIP). In EIP mode, ions fragmented in the collision cell (Q2) were captured in the ion trap and then scanned. In the IDA method, Q3 survey scans were used to automatically trigger an EIP scan if the signal was above a threshold of 500,000 cps. EPI spectra were acquired from 50 to $1000 \mathrm{Da}$ with a scan speed of $2000 \mathrm{Da} \mathrm{s}^{-1}$ and a collision energy (CE) of $45 \mathrm{~V}$ with a collision energy spread (CES) of $20 \mathrm{~V}$. The linear ion trap fill time was $50 \mathrm{~ms}$. Dynamic exclusion was activated to minimise the risk of missing the 
co-eluting compounds. Data acquisition and processing were done using Analyst QS® 1.5.1 software. Relative contribution of particular oligopeptides in their total amount was estimated on the basis of peak area of the pseudo-molecular ions.

\section{Acute toxicity bioassays}

The toxicity of MC-LR (Alexis), ANTX (Torcis, Bioscence) and five aquatic extracts of different cyanobacterial bloom samples containing MCs or both MCs and ANTX as well as other oligopeptides towards the juvenile freshwater rotifer Brachionus calyciflorus Pallas (Rotoxkit F) and the cladoceran Daphnia pulex Leyding (Daphtoxkit $\mathrm{F}^{\mathrm{TM}}$ pulex) was evaluated in 24-h bioassays. In each replicate, five specimen of B. calyciflorus or D. pulex were exposed in $0.3 \mathrm{~mL}$ or $1 \mathrm{ml}$ of standard medium, respectively. The assays were performed under the same laboratory conditions (temperature $20^{\circ} \mathrm{C}$, in darkness), according to the producer (Microbiotests, INC, Gent, Belgium) protocols using different concentrations of MC-LR or ANTX and a range of dilutions of cyanobacterial extracts in a standard medium. The biomass of the extracted cyanobacterial materials was expressed as chl-a concentrations and ranged in the tests from 0.16 to $6.66 \mathrm{mg} \mathrm{Chl-a/L}$. Four dilutions of each extract of Microcystis spp. (A), P. agardhii I (B) and P. agardhii II (C) containing MCs, and four dilutions of each extract of $D$. flos-aquae (D) and D. lemmermannii (E) containing both MCs and ANTX, were tested. The assays were performed three times, in three replicates. The test end-point was the death of the organisms. As controls, in the tests with the extracts and ANTX, the organisms were incubated in the standard medium. The influence of $0.5 \%$ methanol (a maximum concentration used as a solvent for pure MC-LR only) on the survivorship of rotifers and cladocerans was also examined and no toxic effect was observed.

\section{Toxicity data analysis and statistical analysis}

Toxicity data obtained in the bioassays were expressed as the percentage (\%) of the organisms' survivorship as compared to the controls. Data were expressed as means \pm standard error of the mean (SEM). Significant differences among treatments were evaluated using one-factor analysis of variance (ANOVA). Pair-wise comparison of means was done using the Tukey test $(p<0.05)$. For determination of the acute toxicity parameter (24-h LC50), Probit analysis was used. LC50 values with non-overlapping 95\% intervals were regarded as being significantly different. Correlations between the concentrations of pure MC-LR, ANTX or extracts and the survivorship of rotifers and daphnids were calculated using the Pearson coefficient at $p<0.05$.

\section{Results}

\section{Differences in secondary metabolites produced by cyanobacteria}

The extracts obtained from different biomasses (7.90-115.51 mg $\mathrm{Chl}-\mathrm{a} / \mathrm{L}$ ) of bloom-forming cyanobacteria contained high total concentrations of MCs only $(5.00-14.80 \mathrm{mg} / \mathrm{L}$, extracts A, B and C) or both MCs and ANTX together $(0.37-10.86 \mathrm{mg} / \mathrm{L}$, extracts $\mathrm{D}$ and $\mathrm{E}$ ) but in different proportions (Table 1). The biomasses of Microcystis spp. (A) and P. agardhii I (B), sampled from different lakes were characterised by high ratio of the total MC content to Chl-a ( 0.633 and 0.499 , respectively). They were additionally analysed for oligopeptides other than MCs (Table 2). The extract A (Microcystis spp.) contained five MCs and seven other oligopeptides (mainly cyanopeptolins). The

Table 2 MC variants and other oligopeptides identified by means of LC-MS/MS in two cyanobacterial extracts used in bioassays

\begin{tabular}{|c|c|c|c|}
\hline \multirow[t]{2}{*}{$\mathrm{MC}$ variants } & \multirow{2}{*}{$\begin{array}{l}{[\mathrm{M}+\mathrm{H}]^{+}} \\
m / z\end{array}$} & \multicolumn{2}{|l|}{ Extracts } \\
\hline & & $\begin{array}{l}\text { Microcystis spp. } \\
\text { (A) }\end{array}$ & $\begin{array}{l}\text { P. agardhii } \\
\text { (B) }\end{array}$ \\
\hline$\left[\mathrm{Asp}^{3}\right] \mathrm{MC}-\mathrm{HtyR}$ & 1045 & ++ & ++ \\
\hline$\left[\mathrm{Asp}^{3}\right] \mathrm{MC}-\mathrm{HarR}$ & 1038 & +++ & \\
\hline$\left[\mathrm{Ser}^{7}\right] \mathrm{MC}-\mathrm{RR}$ & 1042 & & +++ \\
\hline$\left[\mathrm{Asp}^{3} \mathrm{Mdha}^{7}\right] \mathrm{MC}-\mathrm{RR}$ & 1024 & & +++ \\
\hline MC-LR & 995 & +++ & \\
\hline$\left[\mathrm{Asp}^{3}\right] \mathrm{MC}-\mathrm{LR}$ & 981 & + & \\
\hline$\left[\mathrm{Asp}^{3} \mathrm{dha}^{7}\right] \mathrm{MC}-\mathrm{LR}$ & 981 & & +++ \\
\hline MC-LY & 1002 & + & \\
\hline \multicolumn{4}{|l|}{ Other oligopeptides } \\
\hline Anabaenopeptin A & 844 & +++ & +++ \\
\hline Anabaenopeptin B & 837 & ++ & +++ \\
\hline Anabaenopeptin 915 & 916 & & +++ \\
\hline Anabaenopeptin F & 851 & & +++ \\
\hline Oscillamide Y & 858 & & +++ \\
\hline Aeruginosamide & 561 & +++ & \\
\hline Cl-aeruginoside 126 & 749 & & +++ \\
\hline Aeruginoside 716 & 717 & & +++ \\
\hline Aeruginoside $126 \mathrm{~A}$ & 715 & & +++ \\
\hline Aeruginoside 126 B & 691 & & +++ \\
\hline Aeruginosin 89 & 637 & & +++ \\
\hline Dechloro-aeruginosin 89 & 603 & & ++ \\
\hline Cyanopeptolin CPL997 & 998 & + & \\
\hline Cyanopetolin CPL917 & 918 & + & \\
\hline Cyanopeptolin CPL863 & 863 & ++ & \\
\hline Cyanopeptolin CPL827 & 828 & ++ & \\
\hline
\end{tabular}

Relative contribution of particular peptides found in extracts based on signal intensity. (Counts per second) cps $\times 10^{6}$ low $(+) ; \times 10^{7}$ medium $(++) ; \times 10^{8}$ high $(+++)$ 
extract B ( $P$. agardhii I) contained four MCs and 11 other oligopeptides (anabaenopeptins and aeruginosins). In other three cyanobacterial biomasses, only ANTX and MCs, due to a lack of material, were analysed. On the basis of the signal intensity of pseudo-molecular ions (data not shown), it was concluded that out of the detected metabolites, the relative content of MC-LR and $\left[\mathrm{Asp}^{3}\right] \mathrm{MC}-\mathrm{HarR}$ in extract A was the highest followed by anabaenopeptin A (AP A) and aeruginosamide (AERMD). Three other $\mathrm{MC}$ variants, anabaenopeptin $\mathrm{B}$ and four variants of cyanopeptolins were also present (Table 2). In extract B, from the biomass of $P$. agardhii I (97\%) with an inessential admixture of some Nostocales, two derivatives of MC-RR, [ $\left.\mathrm{Asp}^{3} \mathrm{dha}^{7}\right] \mathrm{MC}$ LR, five anabaenopetins, aeruginosin 89 and five aeruginosides had similarly high relative contribution (Table 2 ). In extract $\mathrm{C}$, obtained from about fourfold higher biomass (115.51 mg Chl-a/ L) of $P$. agardhii II (99\%; Table 1), in which only MCs were detected, the desmethyl derivative of MC-RR predominated over two other MC variants (data not shown). However, the total MC concentration in the $P$. agardhii II extract (MCs to Chl-a ratio
0.047) was about threefold lower than in the case of extract B from the $P$. agardhii I biomass sampled from the same lake but in different season. Extract D, obtained from D. flos-aquae (98\% of biomass) and Aph. gracile (2\%), contained mainly ANTX (0.31 $\mathrm{mg} / \mathrm{L}$ ) and fivefold lower concentration of MCs (MC-LY and two unidentified $\mathrm{MC}$ variants). Altogether, in the extract $\mathrm{D}$ cyanotoxins (MCs and ANTX) to Chl-a ratio was 0.0345 (Table 1). Extract E, from D. lemmermannii (99\% of biomass) and other Dolichospermum spp. (1\%), contained much higher total concentration of microcystins $(8.81 \mathrm{mg} / \mathrm{L})$ than the extract $\mathrm{D}$, with nine different $\mathrm{MC}$ variants (MC-LA, MC-LR, MC-YR, MC-LW, MC-LF and four unidentified) and ANTX (2.05 mg/ L). Cyanotoxins to Chl-a ratio in the extract was 0.154 .

\section{Effect of pure cyanotoxins on zooplankton}

High concentrations (1.66-3.32 mg/L) of pure MC-LR (Fig. 1a) caused an acute toxic effect on $D$. pulex, only (Fig. 1a, Table 4). However, for D. pulex, the 24-h LC50
Fig. 1 The influence of pure MCLR (a) and ANTX (b) on the survivorship of $B$. calyciflorus and $D$. pulex (mean $\pm \mathrm{SEM} ; n=$ 9). The survivorship of organisms in controls was set as $100 \%$.

Different uppercase letters (A, B) indicate statistically significant differences between the survivorship of zooplankters exposed to different concentrations of MC-LR (a) and ANTX (b) (ANOVA, Tukey's test, $p<0.05)$
B. calyciflorus

వ D. pulex

a
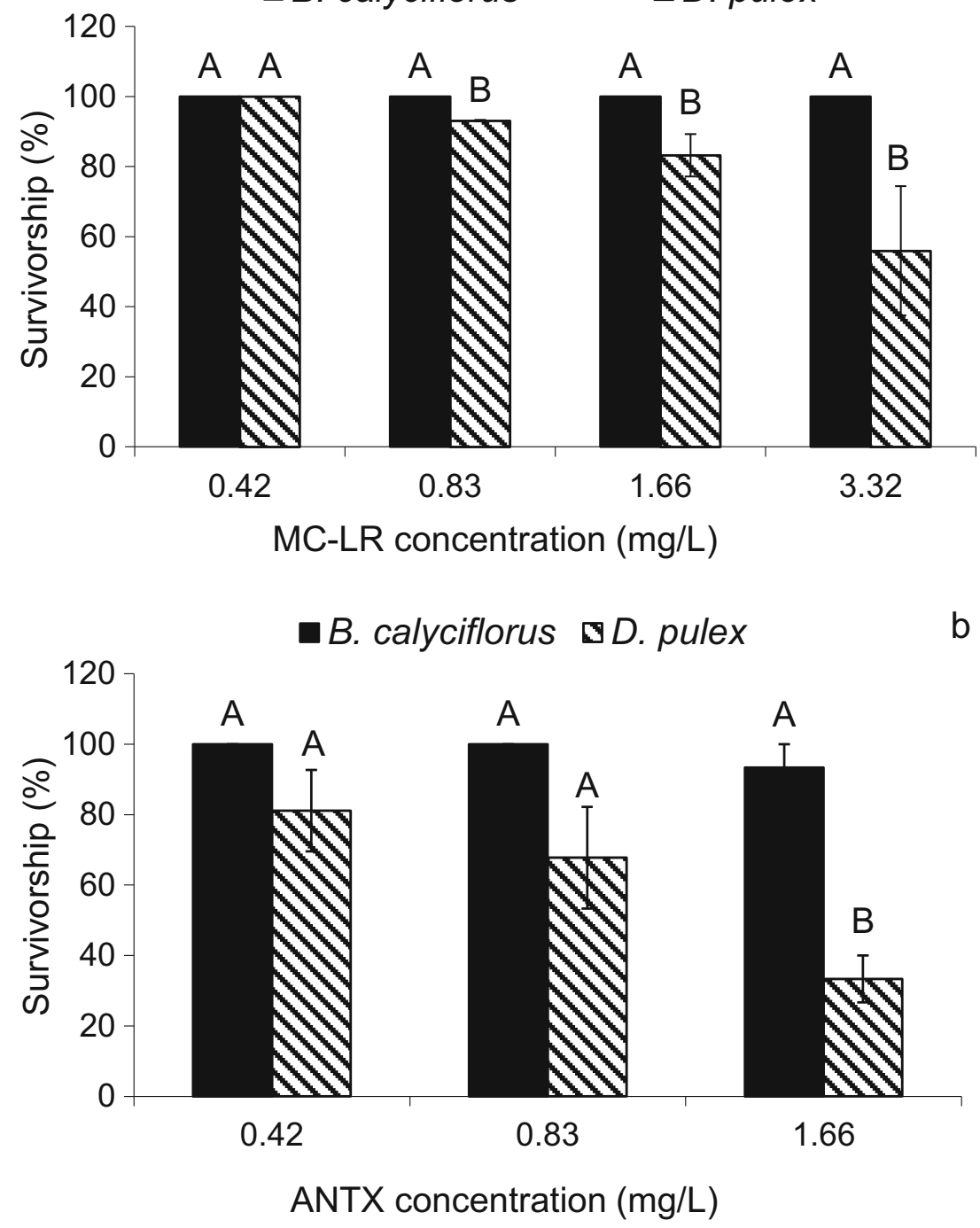
value of MC-LR seems to be higher than $3.32 \mathrm{mg} / \mathrm{L}$, and it was impossible to determine it within the concentration range used. For B. calyciflorus, MC-LR was non-toxic within the range $0.42-3.32 \mathrm{mg} / \mathrm{L}$ (Fig. 1a). The bioassays showed that $B$. calyciflorus was also more resistant than D. pulex to pure ANTX (Fig. 1b, Table 4). ANTX decreased significantly the survivorship of cladoceran to approx. $33 \%$ at the highest concentration used $(1.66 \mathrm{mg} /$ L) and the effect of ANTX was stronger than of MC-LR at the same concentrations (Fig. 1b, Table 4). The 24-h LC50 values of ANTX for D. pulex and B. calyciflorus, however, were not determined within the concentration range used.

\section{Effect of metabolites contained in aqueous cyanobacterial extracts on zooplankton}

The dilutions of the extract of Microcystis spp. (A) and the extract (B) of the biomass composed mainly of $P$. agardhii I (Fig. 2a, b), had similar chlorophyll-a concentrations (max, 1.3 and $1.4 \mathrm{mg} \mathrm{Chl-a/L}$, respectively) and similar range of total MC concentrations (Fig. 2a, b), however, they differed considerably in the profile of MCs and other oligopeptides (Table 2). Toxic effects of these cyanobacterial extracts on the tested organisms were also different (Fig. 2a, b). Extract A, containing five MCs and seven other oligopeptides (with the relatively highest contribution of AP A and AERMD and lower of cyanopeptolins; Table 2), did not exert acute toxic effects neither to rotifers nor to cladocerans (Fig. 2a, Table 4). However, extract B (Table 2), containing a higher number (11) of other oligopeptides than extract A, and four other MC variants (Table 2) was not essentially toxic to rotifers but significantly decreased cladoceran survivorship (approximately to $13 \%$ of the control; Fig. 2b, Table 4).

The dilutions of extract C (from P. agardhii II) with higher Chl-a concentrations (max, $6.66 \mathrm{mg} \mathrm{Chl}-\mathrm{a} / \mathrm{L}$ ) and slightly lower concentrations of MCs than extracts A and B, but an unknown content of other oligopeptides, were significantly toxic to both tested organisms, however, in a contrary to extracts $\mathrm{A}$ and $\mathrm{B}$, much more to B. calyciflorus than to D. pulex (Fig. 2c, Tables 3 and 4). For example, in the diluted extract $C$ containing $0.055 \mathrm{mg} \mathrm{MCs} / \mathrm{L}$, the survivorship of rotifers decreased on average by $83 \%$, whereas survivorship of cladocerans was reduced by $25 \%$ in comparison with untreated organisms. The extract dilutions with several times higher MC concentrations caused $100 \%$ mortality of rotifers (Fig. 2c). The 24$\mathrm{h}$ LC50 value of the extract C (based on the Chl-a concentration; Table 3$)$ for B. calyciflorus $(0.587 \mathrm{mg} \mathrm{Chl-a/L})$ was approx. fourfold lower than for D. pulex (2.433 mg Chl-a/L).

The extracts $\mathrm{D}$ and $\mathrm{E}$ of the biomasses of different species of Dolichospermum containing both MCs and ANTX (in different proportions) but unknown amounts of other oligopeptides were also significantly toxic to the organisms
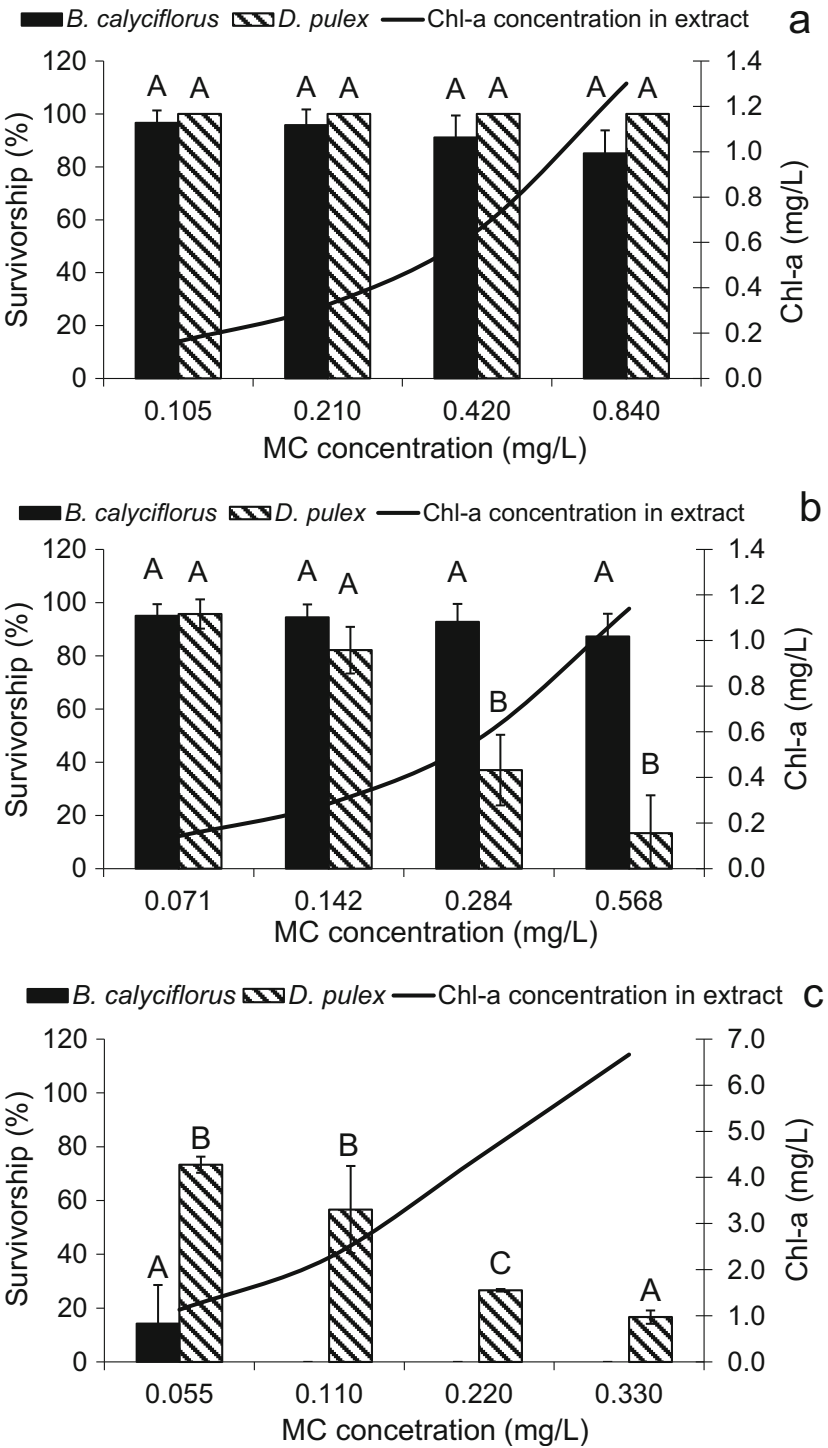

Fig. 2 The influence of extracts of MC-producing Microcystis spp. (a), $P$. agardhii I (b) and P. agardhii II (c) on the survivorship of B. calyciflorus and D. pulex (mean $\pm \mathrm{SEM} ; n=9$ ). The survivorship of organisms in controls was set as $100 \%$. Different uppercase letters (A, B, C) indicate statistically significant differences between the survivorship of zooplankters exposed to different dilutions of extracts of Microcystis spp. (a), P. agardhii I (b) and P. agardhii II (c) with determined cyanotoxins and Chl-a concentrations (ANOVA, Tukey's test, $p<0.05$ )

tested (Fig. 3a, b, Table 4). The D. flos-aquae extract (D), at low total cyanotoxins' concentrations (up to $0.056 \mathrm{mg} / \mathrm{L}$ ) containing sixfold higher ANTX than MCs (Fig. 3a), exerted a similar acute toxic effect on rotifers and cladocerans. As indicated by correlation coefficient (Table 4), the survivorship of rotifers and cladocerans decreased also significantly after short-term exposure to extract $\mathrm{E}$ from $D$. lemmermannii (Fig. 3b). The extract $\mathrm{E}$ was more toxic to rotifers (24-h LC50 $=0.774 \mathrm{mg} \mathrm{Chl-a/L)} \mathrm{than} \mathrm{to} \mathrm{cladocerans}(24-\mathrm{h} \mathrm{LC50} \mathrm{=}$ $1.234 \mathrm{mg} \mathrm{Chl}-\mathrm{a} / \mathrm{L}$ ). The dilutions of the extract $\mathrm{E}$ used in the test contained almost 21-fold higher concentrations of MCs and slightly lower ANTX concentrations than in the extract D, but 
Table 3 Toxicity (24-h LC50) of MCs or MCs and ANTX containing cyanobacterial extracts to $B$. calyciflorus and $D$. pulex, determined on the base of cyanobacterial Chl-a concentration used as the equivalent of the cyanobacterial biomass

\begin{tabular}{lll}
\hline Extract code & \multicolumn{2}{l}{ LC50 expressed as mg Chl-a/L } \\
\cline { 2 - 3 } & Brachionus calyciflorus & Daphnia pulex \\
\hline A & n.d. & n.d. \\
B & n.d. & $0.475 \pm 0.053$ \\
C & $0.587 \pm 0.039$ & $2.433 \pm 0.231$ \\
D & n.d. & n.d. \\
E & $0.774 \pm 0.040$ & $1.234 \pm 0.207$ \\
\hline
\end{tabular}

n.d. not determined within the extract concentration range used

Data are expressed as means $\pm 95 \%$ confidence intervals

affected B. calyciflorus more strongly than D. pulex (Fig. 3a, b). At the lowest dilution of the extract $\mathrm{E}$ from $D$. lemmermannii containing the highest cyanotoxins' concentration, a 100\% lethal effect on both organisms was observed (Fig. 3b).

\section{Discussion}

In recent years, progressive water eutrophication and predicted climate warming have prompted interest in toxigenic cyanobacterial blooms (Rigosi et al. 2014) and their effects on the functioning of aquatic biocenoses and ecosystems (Pawlik-Skowrońska et al. 2013; Toporowska and PawlikSkowrońska 2014; Toporowska et al. 2014; Ger et al. 2014; Sukenik et al. 2015). Daphnids (Cladocera) and rotifers (Rotifera) play important roles in various water bodies as a part of food chains (Ger et al. 2014).

Experiments with single MC-LR and ANTX showed that very high concentrations of toxins present in water can exert acute toxic effects on zooplankton. However, in nature, aquatic organisms face the mixtures of various metabolites present both in cyanbacterial cells and in water

Table 4 Values of Pearson's coefficients showing correlation between the concentrations of pure MC-LR, ANTX, cyanobacterial extracts and survivorship of $B$. calyciflorus and D. pulex

\begin{tabular}{lll}
\hline & B. calyciflorus & D. pulex \\
\hline MC-LR & 0 & $-0.58 * *$ \\
ANTX & -0.46 & $-0.74 * *$ \\
A & -0.37 & 0 \\
B & -0.30 & $-0.84 * *$ \\
C & $-0.91 *$ & $-0.80^{* *}$ \\
D & $-0.75 * *$ & $-0.77 * *$ \\
E & $-0.89 * *$ & $-0.97 * *$ \\
\hline
\end{tabular}

A-E, codes of extracts. Significant results in italics; $* 0.05<p<0.01$, $* * 0.01<p \leq 0.001$ after cell lysis (Metcalf and Codd 2012). Therefore, we compared the effects of five natural mixtures of cyanobacterial metabolites (ANTX, MCs and other oligopeptides) present in aqueous extracts of different bloom samples on different invertebrates of zooplankton communities.

Our results indicate that rotifers were, generally, more resistant than daphnids to pure toxins (ANTX and MC-LR). However, the toxicity of cyanotoxins can be species-specific and may depend on the exposure route - cyanobacterial cell ingestion and/or absorption of dissolved toxins. As previously reported by Gilbert (1994), survivorship of the rotifer Synchaeta pectinata Ehrenberg was already affected at $0.20 \mathrm{mg} \mathrm{ANTX/L}$, whereas the survivorship of $D$. pulex did not decrease at $1 \mathrm{mg}$ of ANTX/L; however, the day of first reproduction or interclutch interval were affected in a temperature-dependent manner. Toxicity of MCs towards daphnids has been previously reported (Wiegand and Pflugmacher 2005) and it was found that the lethal effects depend on the amount of toxin accumulated in different species and type of feeding. As reported by Tonk et al. (2005), different $\mathrm{MC}$ variants may reveal various toxicity. For example, more hydrophobic MC-LW, MC-LF were more toxic in vivo to invertebrates than MC-LR and MC-LY variants (Ward and Codd 1999). Therefore, the effects that were observed here have been a consequence of physical-chemical variation and different bioactivity of various cyanobacterial metabolites as well as sensitivity of individual species or even populations of aquatic invertebrates.

Our experiments confirmed much higher toxicity of the cyanobacterial extracts containing mixtures of various cyanotoxins and other cyanobacterial metabolites than of pure MC-LR and ANTX used in equivalent concentrations. The influence of cyanobacterial extracts containing natural mixtures of several cyanobacterial metabolites on zooplankton has been extensively studied (Hulot et al. 2012; Smutná et al. 2014; Barrios et al. 2015). However, only a few of these works characterised extracts for other metabolites than cyanotoxins. Our study revealed that of the two extracts tested, from Microcystis spp. (A) and from P. agardhii I (B), only the extract of $P$. agardhii was toxic to daphnids and none of them to rotifers. $M$. aeruginosa, which predominated in cyanobacterial biomass in extract $\mathrm{A}$, was previously classified (Tillmanns et al. 2008 and references therein) as one of the most harmful species to zooplankton (independent of its MC production) in case of ingestion of its cells. Both extracts tested were characterised by high MC to Chl-a ratios but differed considerably in other oligopeptide's profile. Similar high ratios were reported for some strains of $M$. aeruginosa by Lürling et al. (2017). Microcystis spp. in our study produced five variants of MCs, four cyanopeptolins (CPL), two anabaenopeptins (APs) and one aeruginosamide, however, other oligopeptides, reported for Microcystis spp. (Welker and Döhren 2006) such as microginins, microviridins and 
Fig. 3 The influence of extracts of MC- and ANTX-producing D. lemmermannii $(\mathbf{b})$ on the survivorship of $B$. calyciflorus and $D$. pulex (mean $\pm \mathrm{SEM} ; n=$ 9). The survivorship of organisms in controls was set as $100 \%$. C) indicate statistically significant differences between the survivorship of zooplankters exposed to different dilutions of extracts of $D$. flos-aque (a) and D. lemmermannii (b) with determined cyanotoxins and Chla concentrations (ANOVA, Tukey's test, $p<0.05)$. n.d. not determined D. flos-aque (a) and Different uppercase letters (A, B,
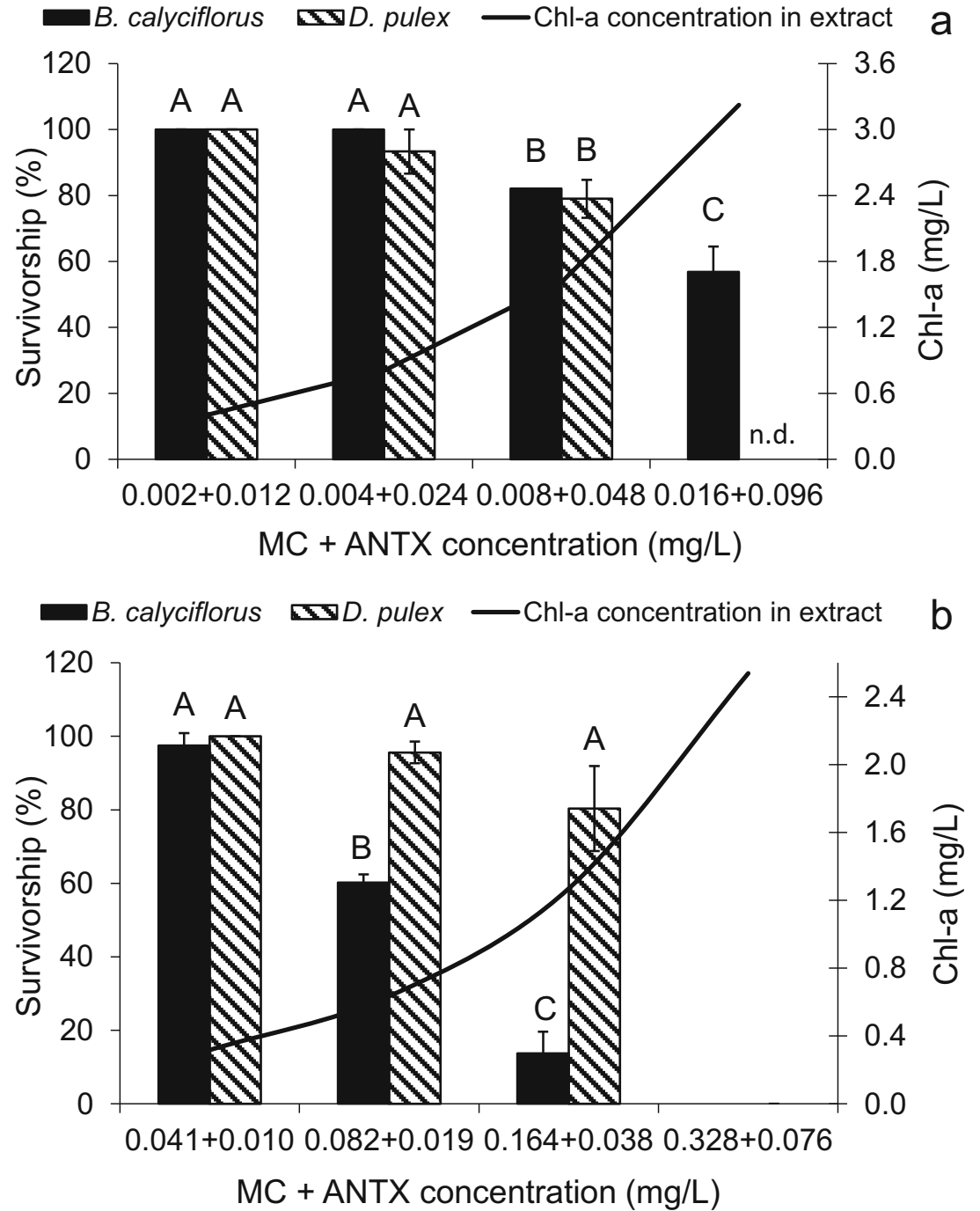

cyclamides were not detected. Czarnecki et al. (2006) reported various inhibition of trypsin-like activity in Daphnia caused by different strains of Microcystis. The effect was dependent, among others, on amino-acid composition of cyanopeptolins, but some of their variants together with microginins and microcystins had no effect on Daphnia.

Toxicity of cyanobacterial metabolites dependent also on the exposure route and cyanobacterial cell ingestion was reported to be more deleterious when compared to the dissolved fraction of cyanotoxins (Ferrão-Filho and Kozlowsky-Suzuki 2011). Ingestion and digestion of cyanobaterial cells is considered the primary mechanism of MC uptake by Daphnia (Rohrlack et al. 2005). Non-ribosomal peptide profiles in Microcystis spp. may essentially differ and their structure depends also on environmental factors (Tonk et al. 2009; Schwarzenberger et al. 2013b); therefore, their toxicity to hydrobionts can variate. Oligopeptide profile in the extract B of $P$. agardhii I was different than of Microcystis and the toxicity of the P. agardhii extract to Daphnia increased in a dose-dependent manner. Planktothrix spp. beside MCs, aeruginosins (AERs) and cyclic anabaenopeptins (APs) can also produce microviridins (MDN D-F, J) (Shin et al. 1996; Rohrlack et al. 2004) and cyanopeptolins (Grabowska et al. 2014) and, therefore, different sub-populations can have various oligopeptide profiles which determine their toxicity. Different APs produced by several species of cyanobacteria are potent protease inhibitors (Sivonen and Börner 2008) and in nature are as common as MCs (Rohrlack and Utkilen 2007; Kurmayer et al. 2011; Grabowska et al. 2014). Also, AERs are inhibitors of carboxypeptidase, serine proteases and (like MCs) protein phosphatases (Shin et al. 1998; Baumann et al. 2007; Kohler et al. 2014). Microcystins (inhibitors of protein phosphatases PP1 and PP2A), classified as cyanotoxins, constitute ca. $30 \%$ of oligopeptides produced by cyanobacteria (Janssen 2019 and references therein). It strongly suggests that the toxicity of cyanobacterial extracts is determined by the whole profile of the oligopeptides, not only by MCs or ANTX.

Biological role of cyanobacterial oligopeptides, which are a large group (over 700 structural variants) of mostly nonribosomal metabolites produced by various cyanobacterial 
taxa (Welker and Döhren 2006; Janssen 2019 and references therein), is still unclear and under discussion. Serine proteases, such as trypsin and chymotrypsin, are the most important digestive enzymes in the gut of Daphnia (Von Elert et al. 2004) and occur also in some Rotifera (Hara et al. 1984); however, in rotifers, they may vary considerably between species and individuals as a result of individual differences in feeding activity, age or life stage (Štrojsová and Vrba 2005). It suggests that in natural conditions some oligopeptides may be even more harmful than MCs and ANTX to certain zooplankton species, because digestion inhibitors become active at much lower concentrations than cyanotoxins (Von Elert et al. 2004). Digestive enzyme inhibition would cause starvation and slow death, but cannot explain the acute toxicity observed within $24 \mathrm{~h}$ both in our experiment and previous study with a purified oscillapeptin J (Blom et al. 2006). The acute toxicity of cyanobacterial compounds have been not fully understood, yet and probably may be based on a few different modes of action. For example, MCs beside PPs inhibition caused also other biochemical alterations in zooplankton (e.g. inhibition of activity of glutathione-Stransferases and acetylocholinesterase; Ferrão-Filho and Kozlowsky-Suzuki 2011 and references therein).

The observed species-specific response in this study to the mixtures of various cyanobacterial metabolites is in agreement with some previous reports. For example, Blom et al. (2006) showed that the purified [D-Asp $\left.{ }^{3}(\mathrm{E})-\mathrm{Dhb}^{7}\right] \mathrm{MC}-\mathrm{RR}$ exerted the highest toxicity to crustaceans (Eudiaptomus sp. and Daphnia sp.) and the lowest to the rotifer B. calyciflorus (24 h-LC50 = 1.2, 21.9, $162.9 \mathrm{mg} / \mathrm{L}$, respectively). The toxicity of oscillapeptin J (cyanopeptolin), an efficient inhibitor of trypsin (Baumann et al. 2007), was found only for Eudiaptomus sp. (24 h-LC50 = 64.7 mg/L) and Daphnia sp. (24 h-LC50 = $226.4 \mathrm{mg} / \mathrm{L}$ ) but not for B. calyciflorus (Blom et al. 2006). According to Baumann and Jüttner (2008), P. rubescens containing mostly $\left[\mathrm{Asp}^{3} \mathrm{Dhb}^{7}\right] \mathrm{MC}-\mathrm{RR}$ and oscillapeptin J caused mass mortality of Daphnia sp. in a Swedish lake, whereas copepods were not affected. Hulot et al. (2012) reported that the extract of the $P$. agardhii strain with unknown content of other metabolites but containing $\left[\mathrm{D}-\mathrm{Asp}^{3}\right] \mathrm{MC}-\mathrm{LR},\left[\mathrm{D}-\mathrm{Asp}^{3}\right.$ ]MC-RR and [D-Asp $\left.{ }^{3}\right] \mathrm{MC}-$ HtyR had stronger effects on the survivorship of Daphnia magna Straus than the MC-free strain. However, both extracts (with MCs or MC-free) had disruptive effects on the reproduction of cladocerans. The comparison of effects of two cyanobacterial extracts with similar MC concentrations but different amounts and numbers of other oligopeptides strongly suggest that APs and AERs (produced by $P$. agardhii I) could be more toxic to $D$. pulex than MCs. Therefore, bioactive oligopeptides like anabaenopeptins and aeruginosins should be considered as the class of cyanotoxins. As it is in the case of microcystins, the production of APs and microviridins by $P$. agardhii was linearly correlated to the growth rate and biomass of the cyanobacterium (Rohrlack and Utkilen 2007), although opposite results were also reported (Kosol et al. 2009).

In one lake different strains of the same species may produce (or not) a series of different MCs and other oligopeptides (Czarnecki et al. 2006). For example, in a dam reservoir in Poland, in different years and seasons, from 7 to 22 oligopeptides other than MCs (i.e. anabaenopeptins, aeruginosins, and also single representatives of aeruginosamides, cyanopeptolins and planktocyclins) were found in P. agardhii (Grabowska et al. 2014). Hence, each cyanobacterial bloom can exert different toxic effects. In our study, the metabolites produced by different populations of $P$. agardhii from the same lake (but developed in different years) revealed opposite toxic effects on two zooplankton species. It is quite probable that in the most toxic extract (C) of $P$. agardhii II other oligopeptides were present than in the extract B and therefore, their toxic effects were different: extract $\mathrm{C}$ (more harmful to $B$. calyciflorus than to Daphnia) was obtained from a larger cyanobacterial biomass than extracts A and B and could contain higher number and concentrations of various oligopeptides. Interestingly, even non-MC-producing Planktothrix strain produced aeruginosin $828 \mathrm{~A}$ which inhibited thrombin and trypsin in Thamnocephalus platyurus Packard (Kohler et al. 2014). The relative contribution and abundance of oligopeptides depend on the chemotype structure of cyanobacterial populations and may change in response to environmental factors such as water depth and light intensity (Rohrlack and Utkilen 2007; Agha et al. 2013).

Different species of Dolichospermum can produce a range of different toxins and non-ribosomal oligopeptides with harmful activity to aquatic organisms (Sivonen and Jones 1999; Rouhiainen et al. 2010). The extracts of Dolichospermum spp., containing both ANTX and MCs in different proportions (and unknown number and amount of other oligopeptides) affected rotifers and cladocerans in a dose-dependent manner. D. lemmermannii extract with higher total cyanotoxin concentrations was twofold more toxic to daphnids and almost fivefold more toxic to rotifers than the extract of D. flos-aque. On the other hand, Barrios et al. (2015) reported higher toxicity of crude extract of Dolichospermum planctonicum (Brunnthaler) Wacklin, L.Hoffmann and Komárek (with unknown content of toxic metabolites) to the small cladoceran Ceriodaphnia cornuta G.O. Sars than to the rotifer Plationus patulus (Müller). It suggests that successive mass development of different species/strains of cyanobacteria with complex composition of metabolites causes a real but various threat for different taxonomic groups of zooplankton. 
Generally, our results suggest that secondary cyanobacterial metabolites other than cyanotoxins such as MCs, ANTX or their synergistic interactions contribute to the toxicity observed in daphnids and rotifers. As was reported by Freitas et al. (2014), a mixture of two cyanobacterial extracts, one containing MC-LR, the second one anatoxin-a(S), revealed both additive and synergistic toxicity to feeding rate of D. magna. However, profiles of other metabolites in the extracts were unknown and their influence can not be excluded. It seems that interactions between cyanobacterial metabolites (present in water bodies both intra- and extracellular) and zooplankton may vary between species or genera of the planktonic invertebrates, and in nature they may also depend on environmental factors or the efficiency of detoxification processes, which in the case of MCs rely on the production of MC-GSH conjugates (Wojtal-Frankiewicz et al. 2013) or involvement of cytochrome P450 in the case of ANTX (Wiegand and Pflugmacher 2005). Blom et al. (2006) reported adaptation of cladoceran Daphnia and copepod Eudiaptomus to two intracellular metabolites (oscillapeptin $\mathrm{J}$ and a derivative of MC-RR) present in cyanobacterial diet as a consequence of prolonged exposure to cyanobacterial blooms; however, there is no information concerning rotifers and detoxification processes related to other cyanobacterial metabolites.

\section{Conclusion}

Summing up, the results presented here suggest that natural mixtures of cyanobacterial metabolites (including oligopeptides other than MCs) can be an important selective factor influencing zooplankton communities. Not only concentrations but also a profile of oligopeptides may determine toxicity of cyanobacteria. The resistance of $B$. calyciflorus to pure cyanotoxins (MC-LR and ANTX) was higher than that of D. pulex; however, no evidence for higher resistance of rotifers than daphnids to different mixtures of cyanobacterial metabolites was found. Therefore, different cyanotoxins and other bioactive metabolites, such as oligopeptides, should be accessed as they may pose a risk to aquatic organisms, not only acting in a separated but in an additive or synergistic manner. In addition, each mass development of cyanobacteria, even the ones not producing MCs or ANTX, should be considered as potential threat to zooplankton communities.

Acknowledgements Thanks are expressed to R. Kalinowska for cyanotoxin determination in part of the extracts. The authors would like to acknowledge the European Cooperation in Science and Technology, COST Action ES 1105 "CYANOCOST-Cyanobacterial blooms and toxins in water resources: Occurrence, impacts and management" for adding value to this study through networking and knowledge sharing with European experts and researchers in the field.
Funding information The study was supported by The Polish Ministry of Science and Higher Education, project No. 304396636 (granted to B.P.S.).

\section{Compliance with ethical standards}

Conflict of interest The authors declare that they have no conflict of interest.

Open Access This article is distributed under the terms of the Creative Commons Attribution 4.0 International License (http:// creativecommons.org/licenses/by/4.0/), which permits unrestricted use, distribution, and reproduction in any medium, provided you give appropriate credit to the original author(s) and the source, provide a link to the Creative Commons license, and indicate if changes were made.

Publisher's note Springer Nature remains neutral with regard to jurisdictional claims in published maps and institutional affiliations.

\section{References}

PN-ISO 10260 (2002) Water quality. Measurement of biochemical parameters. Spectrophotometric determination of chlorophyll-a. PWN Warszawa (in Polish)

Agha R, Quesada A (2014) Oligopeptides as biomarkers of cyanobacterial subpopulations. Toward an understanding of their biological role. Toxins 6(6):1929-1950

Agha R, Cirés S, Wörmer L, Quesada A (2013) Limited stability of microcystins in oligopeptide compositions of Microcystin aeruginosa (Cyanobacteria): implications in the definition of chemotypes. Toxins 5:1089-1104

Barrios CAZ, Nandini S, Sarma SSS (2015) Effect of crude extract of Dolichospermum planctonicum on the demography of Plationus platulus (Rotifera) and Ceriodaphnia cornuta (Cladocera). Ecotoxicology 24:85-93

Baumann HI, Jüttner F (2008) Inter-annual stability of oligopeptide patterns of Planktothrix rubescens blooms and mass mortality of Daphnia in Lake Hallwilersee. Limnologica 38:350-359

Baumann HI, Keller S, Wolter FE, Nicholson GJ, Jung G, Süssmuth RD, Jüttner F (2007) Planktocyclin, a cyclooctapeptide protease inhibitor produced by the freshwater cyanobacterium Planktothrix rubescens. J Nat Prod 70:1611-1615

Blom JF, Baumann HI, Codd GA, Jüttner F (2006) Sensitivity and adaptation of aquatic organisms to oscillapeptin $\mathrm{J}$ and [D-Asp3, (E)Dhb7]microcystin-RR. Arch Hydrobiol 167:547-559

Bownik A (2016) Harmful algae: Effects of cyanobacterial cyclic peptides on aquatic invertebrates - a short review. Toxicon 124:26-35

Czarnecki O, Henning M, Lippert I, Welker M (2006) Identification of peptide metabolites of Microcystis (Cyanobacteria) that inhibit trypsin-like activity in planktonic herbivorous Daphnia (Cladocera). Environ Microbiol 8(1):77-87

DeMott WR, Gulati RD, van Donk E (2001) Daphnia food limitation in three hypereutrophic Dutch lakes: evidence for exclusion of largeboded species by interfering filaments of cyanobacteria. Limnol Oceanogr 46:2054-2060

Ferrão-Filho ADS, Kozlowsky-Suzuki B (2011) Cyanotoxins: bioaccumulation and effects on aquatic animals. Mar Drugs 9(12):2729 2772 
Ferrão-Filho ADS, Herrera N, Echeverri F (2014) Microcystin accumulation in cladocerans: first evidence of $\mathrm{MC}$ uptake from aqueous extracts of a natural bloom sample. Toxicon 87(1):26-31

Freitas EC, Pinheiro C, Rocha O, Loureiro S (2014) Can mixtures of cyanotoxins represent a risk to the zooplankton? The case study of Daphnia magna Straus exposed to hepatotoxic and neurotoxic cyanobacterial extracts. Harmful Algae 31:143-152

Geng H, Xie P (2008) Experimental studies on the effects of toxic Microcystis aeruginosa PCC7820 on the survival and reproduction of two freshwater rotifers Brachionus calyciflorus and Brachionus rubens. Ecotoxicology 17(8):709-715

Ger KA, Hansson LA, Lürling M (2014) Understanding cyanobacteriazooplankton interactions in a more eutrophic world. Freshw Biol 59: 1783-1798

Gilbert JJ (1994) Succeptibility of planktonic rotifers to a toxic strain of Anabaena floes-aquae. Limnol Oceanogr 39:1286-1297

Grabowska M, Kobos J, Toruńska-Sitarz A, Mazur-Marzec H (2014) Non-ribosomal peptides produced by Planktothrix agardhii from Siemianówka Dam Reservoir SDR (northeast Poland). Arch Microbiol 196(10):697-707

Han BP, Lin X, Lei L, Gu J (2012) Survivals of D. galeata in sub-tropical reservoirs: harmful effects of toxic cyanobacteria in food source. Ecotoxicology 21(6):1692-1705

Hansson LA, Gustafsson S, Rengefors K, Bomark L (2007) Cyanobacterial chemical warfare affects zooplankton community composition. Freshw Biol 52:1290-1301

Hara K, Arano H, Ishihara T (1984) Some enzymatic properties of alkaline proteases of the rotifer Brachionus plicatilis. Bull Jpn Soc Sci Fish 50:1611-1616

Hulot FD, Carmignac D, Legendre S, Yepremian C (2012) Effects of microcystin-producing and microcystin-free strains of Planktothrix agardhii on long-term population dynamics of Daphnia magna. Ann Limnol Int J Limnol 48:337-347

Janssen EM-L (2019) Cyanobacterial peptides beyond microcystins - a review on co-occurrence, toxicity, and challenges for risk assessment. Water Res 151:488-499. https://doi.org/10.1016/j.watres. 2018.12.048

Jones GJ, Orr PT (1994) Release and degradation of microcystin following algicide treatment of a Microcystis aeruginosa bloom in a recreational lake, as determined by HPLC and protein phosphatase inhibition assay. Water Res 28:871-876

Kohler E, Grundler V, Häussinger D, Kurmayer R, Gademann K, Pernthaler J, Blom JF (2014) The toxicity and enzyme activity of a chlorine and sulfate containing aeruginosin isolated from a non-microcystinproducing Planktothrix strain. Harmful Algae 39:154-160

Komárek J, Anagnostidis K (1999, 2000, 2005) Süßwasserflora von Mitteleuropa. T1, 2: Chroococcales, Oscillatoriales. Spektrum Akademischer Verlag, GmbH, Heidelberg - Berlin - München

Kosol S, Schmidt J, Kurmayer R (2009) Variation in peptide net production and growth among strains of the toxic cyanobacterium Planktothrix spp. Eur J Phycol 44(1):49-62

Kurmayer R, Schober E, Tonk L, Visser PM, Christiansen G (2011) Spatial divergence in the proportions of the genes encoding toxic peptides synthesis among populations of the cyanobacterium Planktothrix in European lakes. FEMS Microbiol Lett 317:127-137

Lawton LA, Edwards C, Codd GA (1994) Extraction and highperformance liquid chromatographic method for the determination of microcystins in raw and treated waters. Analyst 119(7):1525-1530

Leonard JA, Pearl HW (2005) Zooplankton community structure, microzooplankton grazing impact, and seston energy content in the St. Johns river system, Florida as influenced by the toxic cyanobacterium Cylindrospermopsis raciborskii. Hydrobiologia 537:89-97

Lifshits M, Carmeli S (2012) Metabolites of Microcystis aeruginosa bloom material from Lake Kinneret, Israel. J Nat Prod 75(2):209-219
Lürling M (2003) Daphnia growth on microcystin-producing and microcystin-free Microcystis aeruginosa in different mixtures with the green alga Scenedesmus obliquus. Limnol Oceanogr 48:2214-2220

Lürling M, Van Oosterhout F, Faassen E (2017) Eutrophication and warming boost cyanobacterial biomass and microcystins. Toxins 9(2):64

Messineo V, Bogialli S, Melchiorre S, Sechi N, Luglie A, Casiddu P, Mariani MA, Padedda BM, Di Corcia A, Mazzad R, Carlonid E, Brunoa M (2009) Cyanobacterial toxins in Italian freshwaters. Limnologica 39:95-106

Metcalf JS, Codd GA (2012) Cyanotoxins. In: Whitton BA (ed) Ecology of Cyanobacteria II: Their Diversity in Space and Time. Springer Science + Business Media BV pp 651-675

Nasri AB, Bouaïcha N, Fastner J (2004) First report of a microcystincontaining bloom of the Cyanobacteria Microcystis spp. in Lake Oubeira, Eastern Algeria. Arch Environ Contam Toxicol 46:197-202

Osswald J, Rellán S, Carvalho AP, Gago A, Vasconcelos V (2007) Acute effects of an anatoxin-a producing cyanobacterium on juvenile fish Cyprinus carpio L. Toxicon 49:693-698

Pawlik-Skowrońska B, Pirszel J, Kornijów R (2008) Spatial and temporal variation in microcystin concentrations during perennial bloom of Planktothrix agardhii in a hypertrophic lake. Ann Limnol Int J Limnol 44(2):63-68

Pawlik-Skowrońska B, Kalinowska R, Skowroński T (2013) Cyanotoxin diversity and food web bioaccumulation in a reservoir with decreasing phosphorus concentrations and perennial cyanobacterial blooms. Harmful Algae 28:118-125

Pearson LA, Dittman E, Mazmouz R, Ongley SE, D’Agostino PM, Neilan BA (2016) The genetics, biosynthesis and regulation of toxic specilized metabolites of cyanobacteria. Harmful Algae 54:98-111

Rigosi A, Carey CC, Ibelings BW, Brookes JD (2014) The interaction between climate warming and eutrophication to promote cyanobacteria is dependent on trophic state and varies among taxa. Limnol Oceanogr 59(1):99-114

Rohrlack T, Utkilen H (2007) Effects of nutrient and light availability on production of bioactive anabaenopeptins and microviridin by the cyanobacterium Planktothrix agardhii. Hydrobiologia 583:231-240

Rohrlack T, Christoffersen K, Kaebernick M, Neilan BA (2004) Cyanobacterial protease inhibitor microviridin $\mathrm{J}$ causes a lethal molting disruption in Daphnia pulicaria. Appl Environ Microbiol 70:5047-5050

Rohrlack T, Christoffersen K, Dittmann E, Nogueira I, Vasconcelos V, Börner T (2005) Ingestion of microcystins by Daphnia. Limnol Oceanogr 50(2):440-448

Rouhiainen L, Jokela J, Fewer DP, Urmann M, Sivonen K (2010) Two alternative starter modules for the non-ribosomal biosynthesis of specific anabaenopeptin variants in Anabaena (Cyanobacteria). Chem Biol 17:265-273

Schwarzenberger A, D'Hondt S, Vyverman W, von Elert E (2013a) Seasonal succession of cyanobacterial protease inhibitors and Daphnia magna genotypes in a eutrophic Swedish lake. Aquat Sci 75(3):433-445

Schwarzenberger A, Sadler T, Von Elert E (2013b) Effect of nutrient limitation of cyanobacteria on protease inhibitor production and fitness of Daphnia magna. J Exp Biol 216:3649-3655

Shin HJ, Murakami M, Matsuda H, Yamaguchi K (1996) Microviridins D-F, serine protease inhibitors from the cyanobacterium Oscillatoria agardhii (NIES-204). Tetrahedron 52:8159-8168

Shin HJ, Matsuda H, Murakami M, Yamaguchi K (1998) Anabaenopeptins $\mathrm{E}$ and $\mathrm{F}$, two new cyclic peptides from the cyanobacterium Oscillatoria agadhii (NIES-204). J Nat Prod 60:139-141

Sivonen K, Börner T (2008) Bioactive compounds produced by cyanobacteria. In: Herrero A, Flores E (eds) The Cyanobacteria: Molecular Biology, Genomics and Evolution. Caister Academic Press, Norfolk, pp 159-197 
Sivonen K, Jones GJ (1999) In: Chorus I, Bartram J (eds) Toxic Cyanobacteria in Water. Spoon FN, London

Smutná M, Babica P, Jarque S, Hilscherová K, Marsálek B, Haeba M, Bláha L (2014) Acute, chronic and reproductive toxicity of complex cyanobacterial blooms in Daphnia magna and the role of microcystins. Toxicon 79:11-18

Štrojsová M, Vrba J (2005) Direct detection of digestive enzymes in planktonic rotifers using enzyme-labelled fluorescence (ELF). Mar Freshw Res 56(2):189-195

Sukenik A, Quesada A, Salmaso N (2015) Global expansion of toxic and non-toxic cyanobacteria - effect on ecosystem functioning. Biodivers Conserv 24:889-908

Tillmanns AR, Wilson AE, Pick FR, Sarnelle O (2008) Meta-analysis of cyanobacterial effects on zooplankton population growth rate: species-specific responses. Fundam Appl Limnol 171:285-295

Tonk L, Visser PM, Christiansen G, Dittmann E, Snelder EOFM, Wiedner C, Mur LR, Huisman J (2005) The microcystin composition of the cyanobacterium Planktothrix agardhii changes toward a more toxic variant with increasing light intensity. Appl Environ Microbiol 71:5177-5181

Tonk L, Welker M, Huisman J, Visser PM (2009) Production of cyanopeptolins, anabaenopeptins, and microcystins by the harmful cyanobacteria Anabaena 90 and Microcystis PCC 7806. Harmful Algae 8(2):219-224

Toporowska M, Pawlik-Skowrońska B (2014) Four-year study on phytoplankton biodiversity in a small hypertrophic lake affected by water blooms of toxigenic cyanobacteria. Pol J Environ Stud 23(2):491-499
Toporowska M, Pawlik-Skowrońska B, Kalinowska R (2014) Accumulation and effects of cyanobacterial microcystins and anatoxin-a on benthic larvae of Chironomus spp. (Diptera: Chironomidae). Europ J Entomol 111(1):83-90

Von Elert E, Agrawal MK, Gebauer C, Jaensch H, Bauer U, Zitt A (2004) Protease activity in gut of Daphnia magna: evidence an integrated for trypsin and chymotrypsin enzymes. Comp Biochem Physiol B Biochem Mol Biol 137:287-296

Wacklin P, Hoffmann L, Komárek J (2009) Nomenclatural validation of the genetically revised cyanobacterial genus Dolichospermum (Ralfs ex Bornet et Flahault) comb. nova. Fottea 9(1):59-64

Ward CJ, Codd GA (1999) Comparative toxicity of four microcystins of different hydrophobicities to the protozoan, Tetrahymena pyriformis. J Appl Microbiol 86(5):874-882

Welker M, Döhren H (2006) Cyanobacterial peptides - nature's own combinatorial biosynthesis. FEMS Microbiol Rev 30:530-563

Wiegand C, Pflugmacher S (2005) Ecotoxicological effects of selected cyanobacterial secondary metabolites a short review. Toxicol Appl Pharmacol 203:201-218

Wojtal-Frankiewicz A, Bernasińska J, Jurczak T, Gwoździński K, Frankiewicz P, Wielanek M (2013) Microcystin assimilation and detoxification by Daphnia spp. in two ecosystems of different cyanotoxin concentrations. J Limnol 72:154-171 